\title{
academicJournals
}

Vol. 9(6), pp. 212-223, June 2017

DOI: $10.5897 / I J B C 2016.1061$

Article Number: 604F03A64328

ISSN 2141-243X

Copyright (c) 2017

International Journal of Biodiversity and

Author(s) retain the copyright of this article

http://www.academicjournals.org/IJBC

\section{Hydroclimatic variability and flood risk on Naglanou and Akissa forests areas in Mono River Delta (West Africa)}

\author{
Amoussou E..$^{\star}$, Osseni A.A. ${ }^{2}$, Totin Vodounon S. H. ${ }^{1}$, Lange U. ${ }^{2}$ and Preuss S. $^{2}$ \\ ${ }^{1}$ Department of Geography, University of Parakou, BP 123, Parakou, Benin. \\ ${ }^{2}$ Deutsche Gesellschaftfür Internationale Zusammenarbeit (GIZ) GmbH, Germany.
}

Received 27 November, 2016; Accepted 22 April, 2017

\begin{abstract}
This study aims to analyze hydroclimatic variation (meaning rainfall and flow decrease or increase, regime irregularity, ...) in Mono River basin and flood risk for ecological conservation of Naglanou (Benin) and Akissa (Togo) hydrosystems. Climate, hydrology and planimetry data were used for descriptive statistical and spatial interpolation to determine rain/flow relationship, climate balance (rainfall less potential evapotranspiration), flow coefficient (relationship between rainfall and flow), flood risk thresholds (base on Standardized Precipitation Index) return period. Naglanou and Akissa forest areas record heavy rainfall ranging 161 to $277 \mathrm{~mm}$ in June and 90 to $130 \mathrm{~mm}$ in October, representing respectively 16 and $13 \%$ of annual rainfall (1961-2015). This unequal spatiotemporal rainfall distribution determines surface flows and moisture of these forest sites during water level rise periods. Moreover, increase of flow rate by $20.38 \%$ over $1961-2015$ and $14 \%$ over 1961-2000 linked to rainfall since 1990 and impoundment of Nangbeto dam since 1987. Flood hazard thresholds are limited $\left(424.8 \mathrm{~m}^{3} . \mathrm{s}^{-1}\right)$, moderate $\left(609.3 \mathrm{~m}^{3} . \mathrm{s}^{-1}\right)$, significant $\left(709.1 \mathrm{~m}^{3} . \mathrm{s}^{-1}\right)$, and critical $\left(824.1 \mathrm{~m}^{3} . \mathrm{s}^{-1}\right)$. Return periods correspond to $2,10,20$ and 50 years.
\end{abstract}

Key words: Naglanou and Akissa Forest, biodiversity, mono River Delta, standardized precipitation index, flood risk threshold.

\section{INTRODUCTION}

Transboundary Biosphere Reserves were areas of a sustainable natural resources management in West Africa (Davis, 1994; Doumenge et al., 2001; Fournier et al., 2007). But recent population growth and climate change harmful effects has led to deterioration of these ecosystems (Ngandjui and White, 2000; IPCC, 2001; Mengue-Medou, 2002). Indeed, the project "Transboundary Biosphere Reserve of Mono River Delta" led by GIZ under UNESCO-MAB program aims was to contribute in a sustainable development of the ecological

*Corresponding author. Email: ernestamoussou@gmail.com, ajernest@yahoo.fr.

Author(s) agree that this article remains permanently open access under the terms of the Creative Commons Attribution License 4.0 International License 
sites of Naglanou (Benin) and Akissa (Togo) within a global environmental change context. Both of the sites shelter the floodplain forests of the Delta of Mono River. Beck et al. (2013) demonstrates that meso- to macroscale catchment studies ( $>1$ and $>10000 \mathrm{~km}^{2}$, respectively) in the tropics, subtropics, and warm temperate regions have mostly failed to demonstrate a clear relationship between river flow and change in forest area. According to Hughes et al. (2003), changes in floodplain forests have been directly affected by changing nature of river systems as they have responded to climate change.

Then climate change is a potential major threat to environment and sustainable development. There is mounting evidence that climate change is increasing the frequency of extreme hydro-meteorological events such as heat and cold waves, tropical hurricanes, windstorms, flooding and mudslides (IPCC, 2001). This causes loss of life and socioeconomic impacts, compromising significantly development and socioeconomic growth, especially in countries with fewer resources (GFDRR, 2012; Di Minin et al., 2017). Thus in West Africa BeninTogo area in particular, observed climate change over the past forty years induces unavoidable impacts on the Mono River delta hydrological cycle (Amoussou et al., 2012; Tramblay et al., 2014).

Among consequences of this hydroclimatic variation resulting from flood events, are observed loss of life and property, mass migration of people and animals, ecological disasters.

So flood risk constitutes a major concern for planning and land management for ecosystems (GIZ, 2016). Currently, gaps in research exist for country-wide analyses at a fine resolution that encompass the full set of biological and socio-economic data needed to inform conservation decision-making in developing countries (Kukkala and Moilanen, 2013; Kullberg and Moilanen, 2014). On the Mono basin, natural resources are also affected by human activities (land use changes, Nangbeto dam and soon Adjarala dam on the same River). The lack of information about how hydroclimatic variation affects forest ecosystems and ecosystem services on the floodplain is a major constraint to the development of conservation planning. Indeed, effective management of humid tropical forests is a mean way of the prevention of their disappearance as their biological resources in context of climate change (Game et al., 2011) and hydrometeorological risk. Such is the example of swamps and flooded forests of Naglanou in Benin and of Akissa in Togo, located on the Mono River lower valley (Figure 1).

Naglanou and Akissa forest areas are located on the subequatorial climate domain, characterized by two alternative dry and rainy seasons. Sudanian rains through flows contribute also to the provision of water resources to these forests. Linked rain-flow induces submergence of Naglanou and Akissa forest sites during flooding periods,contributing to habitat and biota degradation (GIZ, 2016). Well, both of the two forest sites, on the Mono River flood plain, receive fluvial water. Thus they are characterized by hydromorphic soils and lithosoils on sandstone and types of aquatic vegetation and semi aquatic which constitute ecological habitat for a specific wild fauna.

Therefore, to face global environmental change, the project "Transboundary Biosphere Reserve on the Mono River Delta" aims to contribute to sustainable development of Naglanou (Benin) and Akissa (Togo) ecological sites. 'Zoning of flood-prone lands as ecological reserves or protected wetlands can often help to meet broader environmental or biodiversity goals...' (Dudley et al., 2015). To this end, it is important first to characterize climate and hydrological variation in the Mono River basin and secondary to determine flood risk for ecological conservation of the Naglanou (Benin) and Akissa (Togo) hydrosystems.

\section{METHODOLOGY}

Daily rainfall from databases of the National Meteorology Directorate (DMN) in Benin and Togo and Athiémé station flow data provided by the General Directorate of Water in Benin are used. These climate and hydrological data cover the period 1961-2015. Among the 28 hydrometeorological stations of the Mono Basin, 4 (Anèho, Grand-Popo Tabligbo and Athiémé) near the forest sites help for local level analysis. Also satellite image (Landsat TM scenes and OLI, respectively over a period of 1986 to 2015 years), topography (DTM of STRM30) and field work data were helpful for spatiotemporal analysis.

\section{Hydroclimatic functioning analysis}

Rainfall data distribution mapping by Kriging is made to better analyze spatial hydroclimatic variability on the forest sites. It involves direct estimation of rainfall as well as its variance from daily data of the 28 stations.

To better implement this type of Kriging interpolation, a variogram analysis (Hennequi, 2010) was made to explore data spatial structure and check their autocorrelation. The semivariogram which discloses semi-variance as a distance function between monitoring stations and allows spatially link data was defined as follows:

$$
\gamma(h)=\frac{1}{2} \operatorname{Var}(Z(s+h)-Z(s)) \quad \forall s \in D
$$

or $Z($.$) is the regionalized variable studied is the vector of$ coordinates is the distance vector and is the geographic area studied $\left(21,500 \mathrm{~km}^{2}\right)$.

To characterize surface water resources of the two forest sites, a good knowledge of the hydroclimatic functioning of Mono River basin is necessary.

Rainfall/flow relationship was used to measure the link or dependence level between rains and runoff on the watershed Mono.

Correlation coefficient (Amemiya, 1980; Jobson, 1992; Abudu 


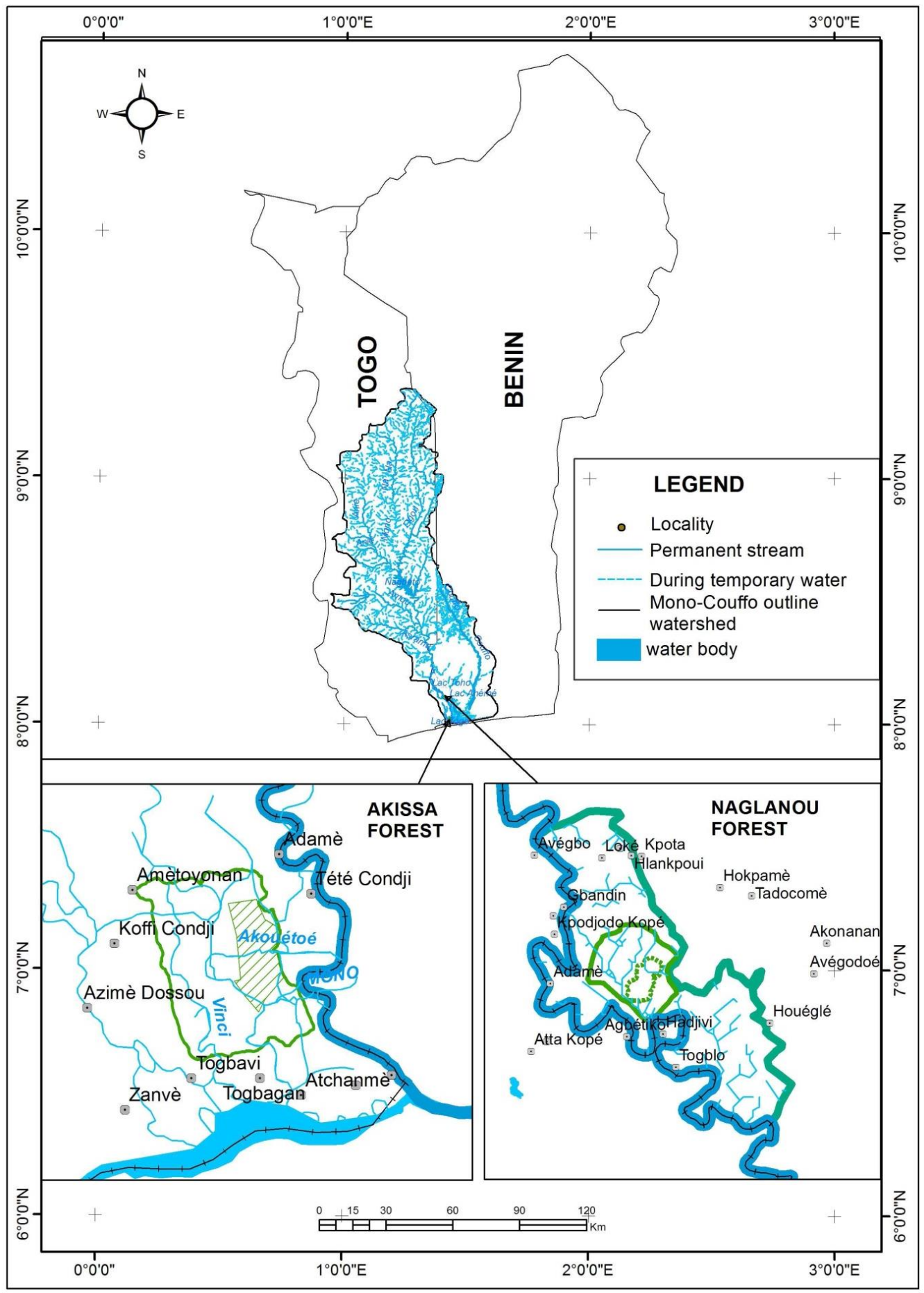

Figure 1. Geographical location of the Naglanou (Benin) and Akissa (Togo) forest areas.

Kasei, 2013) is defined by:

$r=\frac{\frac{1}{N} \sum\left(x_{i}-\bar{x}\right)\left(y_{i}-\bar{y}\right)}{\sigma(x) \cdot \sigma(y)}$
Where $\mathrm{N}$ is the whole individual number; $\mathrm{xi}$ and $\mathrm{yi}$, the series values; $\bar{x}$ and $\bar{y}$ are average rainfall and flow ; $\sigma(x)$ and $\sigma(y)$ represent their standard deviations.

The flow coefficient (C) expresses relationship between rainfall 


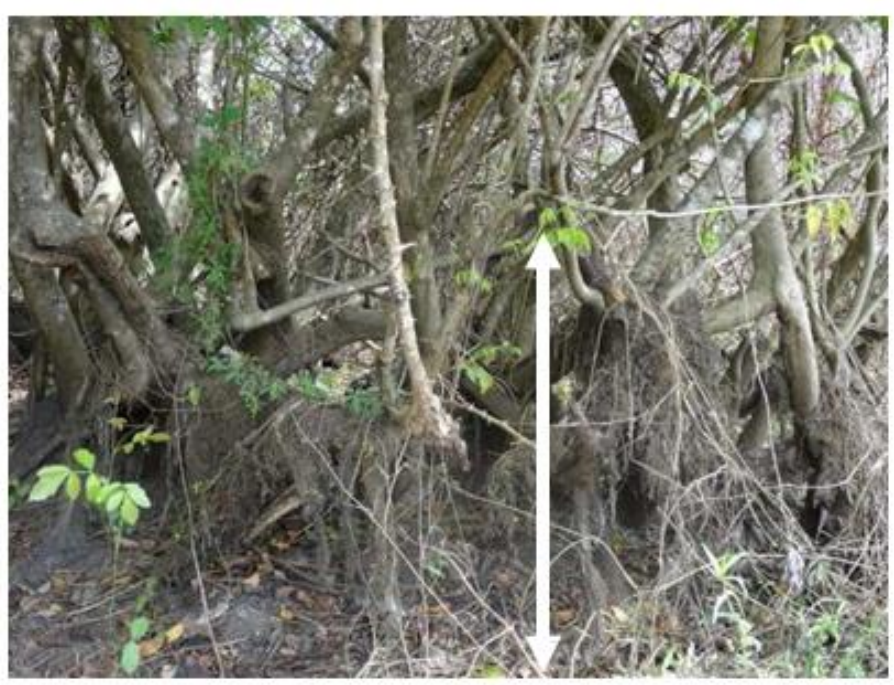

(a)

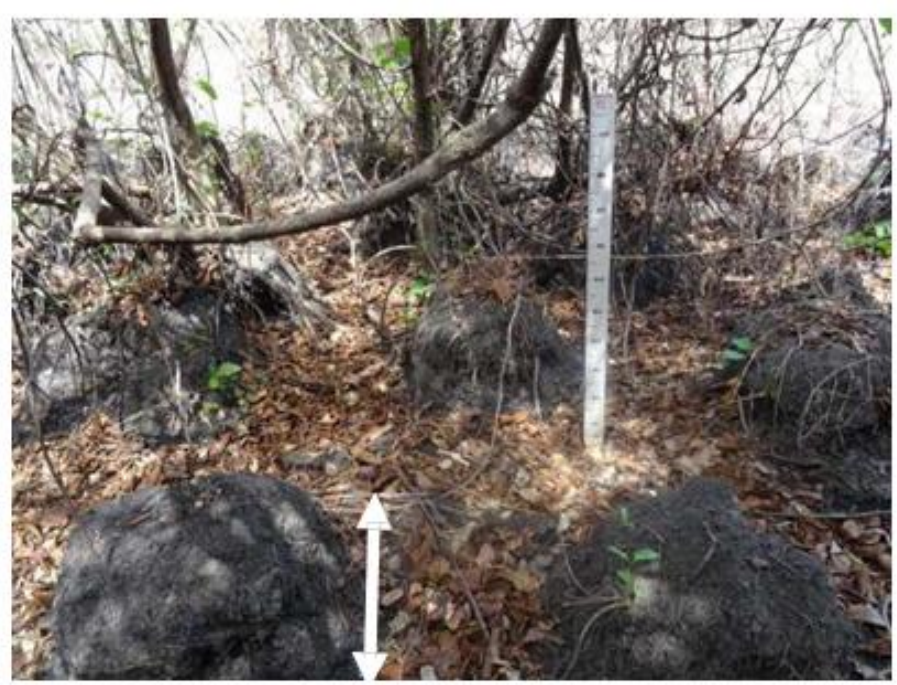

(b)

Photo 1. Water level above soil surface to $110 \mathrm{~cm}$ (a) and $50 \mathrm{~cm}$ (b) at high water periods. Source: Amoussou and Totin (March, 2016).

and runoff (Mahe and Olivry, 1995) and analyzes role played by the geological substratum of Naglanou and Akissa sites in the Mono Basin. It is calculated considering the wet period and cumulative rainfall of the period May-October by the formula: $C=\frac{L}{P} \times 100$, where: $L$ correspond to the flow $(\mathrm{mm})$ and $P$ the rains $(\mathrm{mm})$.

Estimation of the water retention capacity of the Naglanou and Akissa forest sites is by development of slope maps, river systems, determination of wet areas and their depths. The formula used to estimate the volume of mobilized water (Savané et al., 2001) is: $V=S .10^{6} \times H$, with: $\mathrm{V}=$ the volume of mobilized water $\left(\mathrm{m}^{3}\right) ; S$ = the wetted surface area $\left(\mathrm{km}^{2}\right)$ of the site and $H=$ the water depth (m).

On the lowest areas where grasslands are developing, water level on both of the sites is determined from a comparison of interviews results with ecological markers of water level change (Photo 1). So, two water levels data are considered: $50 \mathrm{~cm}$ for less rainy years (Photo $1 \mathrm{~b}$ ) and $110 \mathrm{~cm}$ for exceptional rainfall years (Photo 1a). In almost normal year, seasonal variation in water levels within the limits of $50 \mathrm{~cm}$ is the basis of observed micro-reliefs (gilgaï) formation (Photo 1b) on Naglanou forest site.

The volume mobilized water on Naglanou and Akissa forest sites is evaluated from marshy grassland area and temporal variation in water levels on each of the sites.

\section{Flood risk thresholds on Naglanou and Akissa forests sites}

Detection of rainfall hazards of flood risk is carried from the SPI (Standardized Precipitation Index) and its classifications (McKee et al., 1993; WMO, 2012). The SPI is used for drought analysis (Vicente-Serrano et al., 2010; Karavitis et al., 2011; Dutra et al., 2013; Xie et al., 2013; Trenberth et al., 2014), but it can be good for flooding (Seiler et al., 2002; Guerreiro et al., 2008; Diakakis, 2012; Du et al., 2013). For the flows hazards, the SFI (Standardized Flow Index) of the same formula as SPI (below) was used.

These standardized indices (WMO, 2012) are calculated based on the daily and monthly rainfall for multiple time scales. According to Cancelliere and Bonaccorso (2009), the standardized index is based on an equiprobability transformation of precipitation values aggregated at $\mathrm{k}$-months into standard normal values, with $k$ generally fixed according to the purpose of the analysis (example: $\mathrm{k}$ $=1,3,6,9,12,24,36$ months).

Originally, McKee et al. (1993) propose for the calculation of the SPI Gamma distribution. This index is used with no monthly or multi-monthly time. But for this work, the classic standardized index (denoted Z) was used with time scale change to daily scale. Using rainfall and flow data, it is calculated by the formula: $Z=\frac{Y-\mu}{\sigma}, Y$ is daily rain or flow, $\mu$ and $\sigma$ are respectively the mean and standard deviation of the study series.

In more detail, the standardized precipitation index (SPI) or the normalized flow index (SFI) (Bordi et al., 2001; Lloyd-Hughes and Saunders, 2002; Khadr et al., 2009) is divided as:

$$
S P I / S F I=\left\{\begin{array}{l}
-\left(t-\frac{c_{0}+c_{1} t+c_{2} t^{2}}{1+d_{1} t+d_{2} t^{2}+d_{3} t^{3}}\right), 0<H(x) \leq 0,5 \\
+\left(t-\frac{c_{0}+c_{1} t+c_{2} t^{2}}{1+d_{1} t+d_{2} t^{2}+d_{3} t^{3}}\right), 0,5<H(x) \leq 1,0
\end{array}\right.
$$

Where $\mathrm{t}$ is determined by: $\mathrm{t}=\left\{\begin{array}{l}\sqrt{\ln \frac{1}{(H(x))^{2}}}, 0<H(x) \leq 0,5 \\ \sqrt{\ln \frac{1}{(1-H(x))^{2}}}, 0,5<H(x) \leq 1,0\end{array}\right.$

With the coefficients: $c 0=2.515517 ; \mathrm{c} 1=0.80285$; $c 2=0.010328$; $\mathrm{d} 1=1.432788 ; \mathrm{d} 2=0.189269 ; \mathrm{d} 3=0.001308$.

Detection of rainfall and hydrological thresholds of flood risks was 
Table 1. Classification of SPI values, categories and flood risk levels.

\begin{tabular}{cll}
\hline Class of SPI/SFI & Flood categories & Risk thresholds \\
\hline $2.0+$ & Catastrophic & Critical \\
1.5 to 1.99 & Serious & Significant \\
1 to 1.49 & Negligible & Moderate \\
0 to 0.99 & None effect & Limited \\
\hline
\end{tabular}

Extract from McKee et al. (1993) and WMO (2012) and completed. NB: In the case of work, the operation of Table 1 is made on the values ranging from 0 to 2 and more.

Table 2. Correspondence between standardized indices values and flood risk levels.

\begin{tabular}{clc}
\hline Values of standardized indices & Risk levels & Warning level \\
\hline $2.0+$ & Critical & Red \\
1.5 to 1.99 & Significant & Orange \\
1 to 1.49 & Moderate & Yellow \\
0 to 0.99 & Limited & Green \\
\hline
\end{tabular}

from the categorization of SPI / SFI values (Table 1). This allowed classifying daily rain and flowing data in terms of flood hazards, for different risk levels (limited, moderate, significant and critical) in the Mono River Basin. This hazards categorization has been possible due to a transposition of McKee et al. (1993) classification to use daily data. Thresholds were determined from a standard series of annual daily flows peak at Athiémé hydrometric station. Seasonal cumulative rainfall corresponded to the related years for these thresholds were calculated. Different risk thresholds, into four classes are categorized as shown in Table 2.

\section{Return period of Gumbel method}

Frequency analysis enables to determine recurrence of hydroclimatic events and to estimate their return time (Lubès and Masson, 1991; Hubert and Bendjoudi 1997; Goula et al., 2006; Bois et al., 2007). Frequency model of this prediction is an equation describing the statistical behavior of a process.

The model describes occurrence probability of a hydroclimatic event. A frequency model often used to describe the statistical behavior of extreme values (Ghanmi, 2014) is the statistical Gumbel distribution (double exponential law or Gumbel). Gumbel distribution of law $F(x)$ is expressed as follows:

$$
F(x)=\exp [-\exp ((-x-a) / b)] \text {, }
$$

The reduced variable $u=(x-a) / b$, where $a$ and $b$ are the Gumbel model parameters. The distribution is then written: $F(x)=\exp [-\exp (-u)]$ and $u=-\ln [-\ln (F(x))]$

This is for the purpose of estimating the probability of exceeding $\mathrm{F}(\mathrm{xi})$ to be attributed to each value $\mathrm{xi}$ of rainfall and hydrological series as did by Mimikou et al. (1994); Bonaccorso et al. (2003) and Totin et al. (2009) to determine return periods of normal, abnormal, exceptional (rare) or very exceptional (very rare) hydroclimatic events.
For this empirical frequency Hazen: $r-0,5 / n$, where $r$ is the rank in the series of classified data by increasing values, $n$ the sample size and $x[r]$ the rank $r$ value.

The return period $T$ of a rainy or hydrologic event is defined as the inverse of the probability of the event frequency occurrence.

$$
T=\frac{1}{1-F\left(x_{i}\right)}
$$

\section{RESULTS}

\section{Rainfall and hydrological variability in the catchment of Mono River at Athieme}

Two types of years are distinguished in Mono Delta basin: a wet year with five or six months (May to October) with surplus rainfall ranging from 0.5 to $49.3 \mathrm{~mm}$ and a dry year with two wet months (May-June) with surplus water range from 9.95 to $93.57 \mathrm{~mm}$. Reduction of wet sequences affects the rain/flow relationship which is illustrated by the Figure 2 at Athiémé hydrometric station at the daily time scale. Peak flows are recorded with a shift in precipitation optimum. Years of heavy rains generate abundant flows and therefore heavy flooding in Naglanou and Akissa forest areas. In addition, in dry years, marshes of the Mono Delta are also submerged following the of water release from Nangbéto dam as told by $95 \%$ of the surveyed populations. Dam water releases improve flow and humidify hydromorphic soil of Naglanou and Akissa forest. Thus soil profiles in a state of permanent water saturation, the first rainfall events cause 


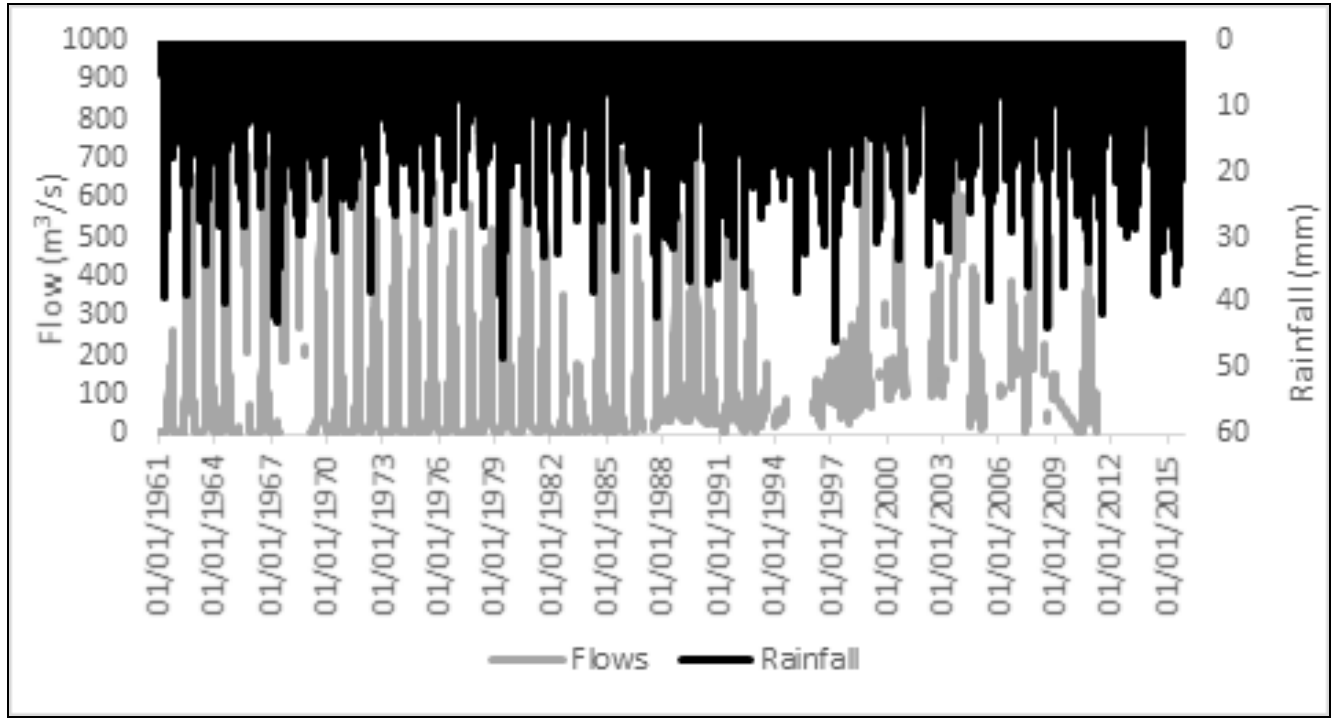

Figure 2. Monthly rainfall / flow relationship on the lower valley at Athiémé.

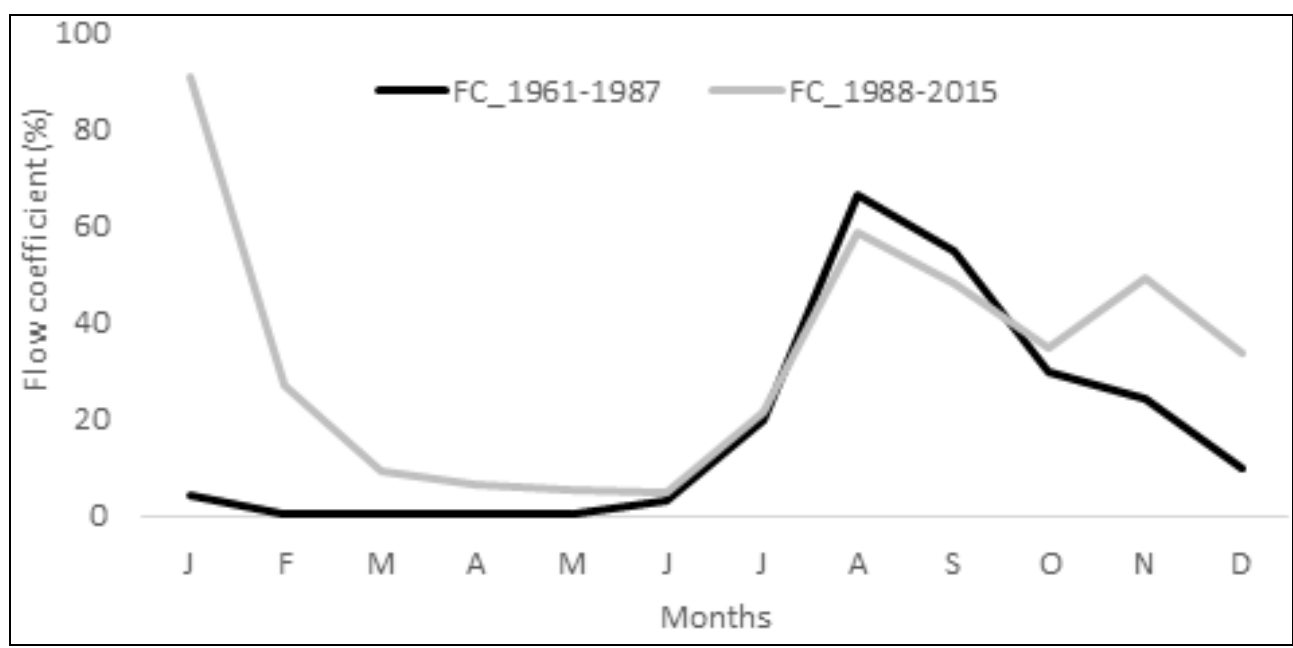

Figure 3. Monthly variation of flow coefficient in the Mono catchment at Athieme.

very quickly floods with a range of water depths $20-55$ $\mathrm{cm}$.

\section{Hydrological incidence of Nangbeto Dam}

Flow coefficient reflects changes on rainfall, role of geological bedrock and impact of vegetation cover (Mounier et al., 1993; Mahé et al., 2000). Runoff coefficient average at Athieme station is $20.38 \%$ over 1961-2015.

Analysis of monthly variation of flow coefficient before and after Nangbéto dam functioning (Figure 3) confirms water increase in recent years on the lower valley, but especially influence of dam water releases.

\section{Water reserves on Naglanou and Akissa forest sites}

Figure 4 shows water accumulation levels and its distribution on Naglanou and Akissa forest areas. Assessment of water volume on Naglanou and Akissa forests need first assessment of the area of marshy grassland area for the years 1986 and 2015. Swampy formations areas have increased from 64.5 to $77.4 \%$ in Akissa and 35.9 to $66.9 \%$ in Naglanou. 

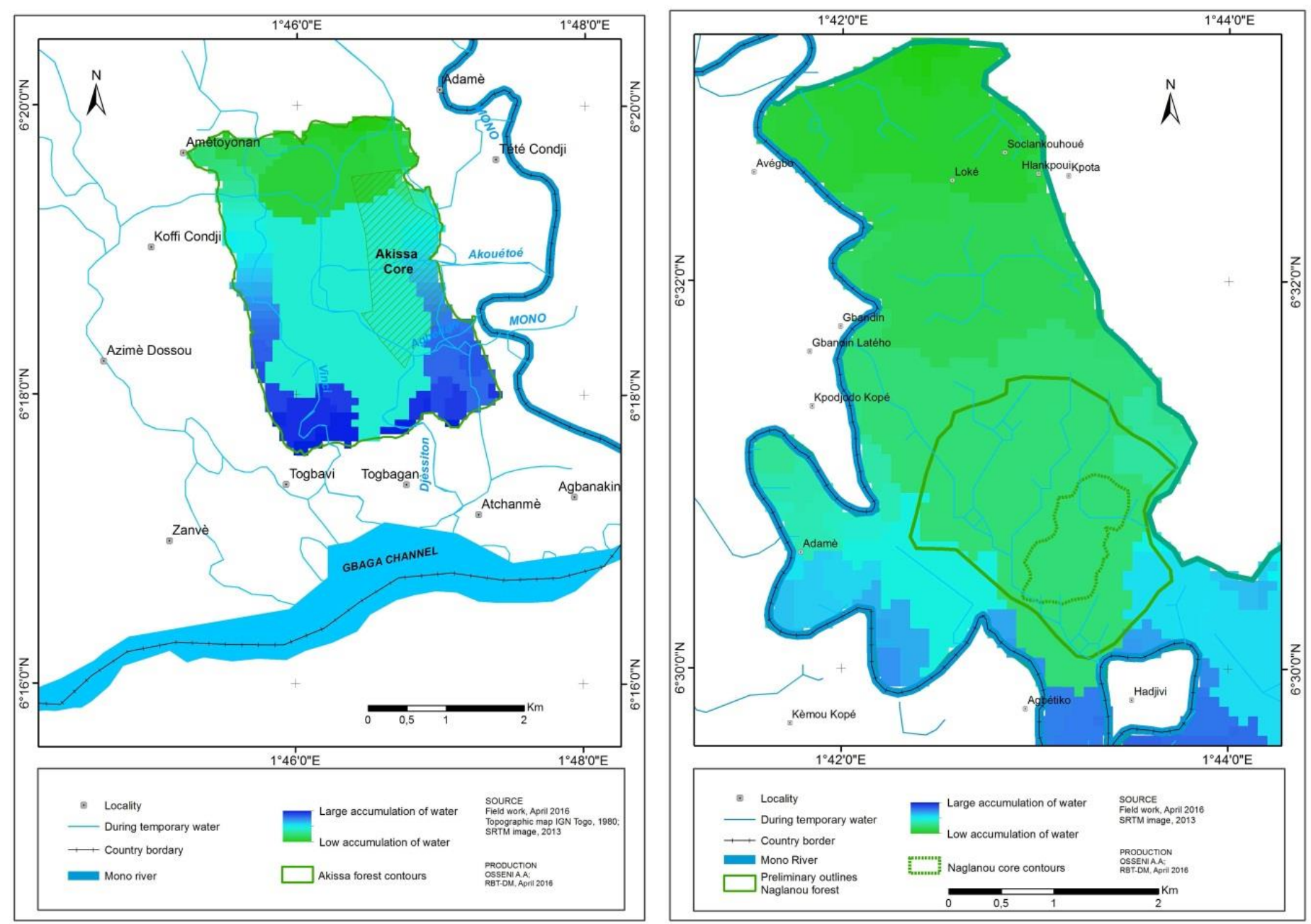

Figure 4. Level and degree of water accumulation on Naglanou and Akissa forest areas.

Table 3 illustrates water volume to be mobilized on the Naglanou and Akissa sites for the two different water levels.

In the dry periods, with substantially $50 \mathrm{~cm}$ water height, only the marshy grassland areas are flooded. On the other hand, in the very wet period (water level $\approx 110$ $\mathrm{cm}$ ), savannas located more on the exposed land is flooded following the grasslands.

Spatiotemporal variation rate of water volume changes by 0.03 to $86.76 \%$ on the forest sites. This variation is more marked at level of $50 \mathrm{~cm}$ water depth (from 20.48 to $86.76 \%$ ) than that of $110 \mathrm{~cm}$ (from 0.03 to $0.49 \%$ ). This low change rate in exceptional rainy year nevertheless shows that these extreme events still occur, but are rare in time. Thus, in recent years, as in the Mono Valley the sites recorded a slight recovery of hydroclimatic events that flood regularly savannas. But water inflows are greater at Naglanou than Akissa.

\section{Flood risks in the forest sites}

Quantitative and qualitative assessment of flood risks on Naglanou and Akissa areas helped in its categorization and deduction of its consequences.

\section{Characterization of hydrometeorological hazards of flood risks}

Characterized flood hazards on Naglanou and Akissa forest sites are extremes rainfall and flow which could lead to the hydro-climatic disaster.

The annual daily peak rates at Athieme from 1961 to 2015 (Figure 5) varies from 90 to $951 \mathrm{~m}^{3} / \mathrm{s}$. These help to identify the various risks of floods thresholds in Naglanou and Akissa sites based on the classification of McKee et al. (1993), implemented in the daily time. 
Table 3. Volume of mobilized water $\left(\mathrm{m}^{3}\right)$ on Naglanou and Akissa forest sites.

\begin{tabular}{l|cc|cc}
\hline Parameter & \multicolumn{2}{|c|}{ Naglanou } & \multicolumn{2}{c}{ Akissa } \\
\hline Water level & $\mathbf{0 . 5} \mathbf{~}$ & $\mathbf{1 . 1 0} \mathbf{~ m}$ & $\mathbf{0 . 5} \mathbf{~}$ & $\mathbf{1 . 1 0 ~ \mathbf { ~ }}$ \\
1986 & 769500 & 4722300 & 3459300 & 11792440 \\
2015 & 1437100 & 4723510 & 4167900 & 11850300 \\
Change rate (\%) & $\mathbf{8 6 . 7 6}$ & $\mathbf{0 . 0 3}$ & $\mathbf{2 0 . 4 8}$ & $\mathbf{0 . 4 9}$ \\
\hline
\end{tabular}

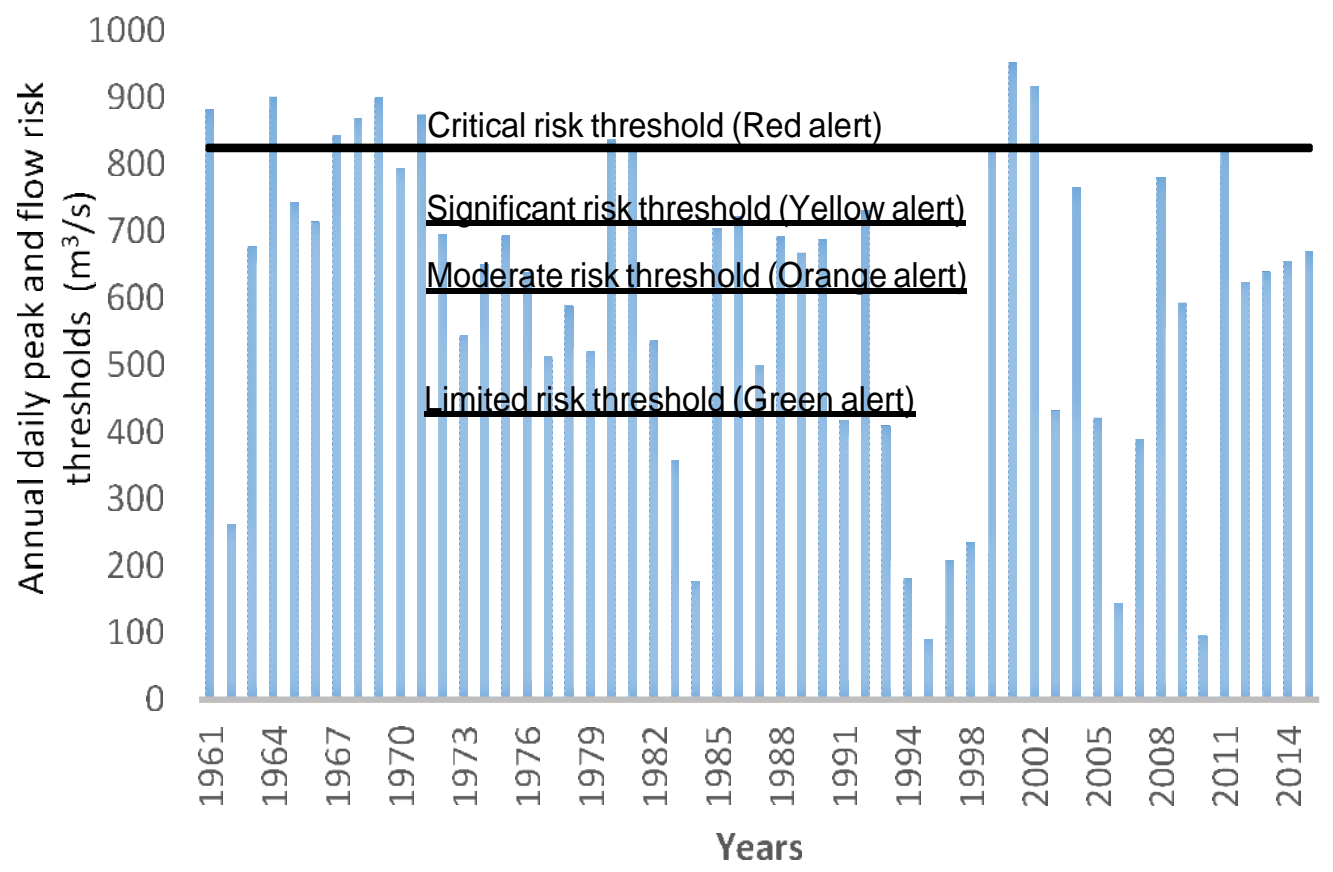

Figure 5. Rates of annual daily flow peak and flood risks thresholds in Naglanou and Akissa forest sites.

Flood hazards showed that $78 \%$ of flow annual peak rates are recorded from September to October. This is consistent with the rainy months (May to October) which concentrate more of $75 \%$ of seasonal rainfall (Houndénou, 1999; Totin et al., 2016) in the Sudanian area where rises the main River that feeds Naglanou and Akissa sites. Flows thresholds are $424.8 \mathrm{~m}^{3} / \mathrm{s}$ for limited flood risk, $609.3 \mathrm{~m}^{3} / \mathrm{s}$ for moderate flood risk, $709.1 \mathrm{~m}^{3} / \mathrm{s}$ for significant flood risk and $824.1 \mathrm{~m}^{3} / \mathrm{s}$ of critical flood risk (Figure 5).

Levels of green and yellow vigilance correspond to hydroclimatic events without major influence on ecological functioning of the forest sites. Moreover, levels of orange and red vigilance refer to the rare frequencies events but catastrophic for biodiversity. In consequence, it is important to establish an early warning system for efficient management of hydroclimatic crises on Naglanou and Akissa forest sites by also focusing on hazards return periods.

\section{Return periods of flood hazards in Naglanou and Akissa forest sites}

Annual daily peak rates on the Mono Basin at Athieme and seasonal cumulative rainfall (May to October) are presented in Table 4.

The rare frequency rates ( $\geq 25$ years or $=50$ years) for wet and very wet recurrences calculated over different periods on the Mono Basin are respectively 1077.5 and $1203.8 \mathrm{~m}^{3} . \mathrm{s}^{-1}$. For normal or abnormal events of frequency $\geq 2$ years or 5 years, or 10 years or 20 years, flow rates were $568.9,772.5,907.3$ and $1036.5 \mathrm{~m}^{3} . \mathrm{s}^{-1}$, respectively.

On the Mono River Delta, high flow rates are due to total seasonal rainfall. Thus, rare frequency flows are generated by total seasonal rain: $1056.4 \mathrm{~mm}$ and 1152.4 $\mathrm{mm}$ for $\geq 25$ years or $=50$ years return period. On the other hand, recurrent rain events ( $\geq 2$ years or 5 years) or of 10 or 20 years frequency are respectively $669.9 \mathrm{~mm}$, 
Table 4. Return periods of seasonal rainfall hazards (May to October) and annual daily flow peak of flood risks on the Mono Basin.

\begin{tabular}{|c|c|c|c|c|c|c|c|}
\hline \multirow{2}{*}{ Stations } & & \multicolumn{6}{|c|}{ Return periods (years) of predicted rainfall $(\mathrm{mm})$} \\
\hline & & 2 years & 5 years & 10 years & 20 years & 25 years & 50 years \\
\hline \multicolumn{8}{|l|}{ Mono River Catchments } \\
\hline \multirow[t]{2}{*}{ Rains jauge } & & 669.9 & 824.6 & 927.1 & 1025.3 & 1056.4 & 1152.4 \\
\hline & Tabligbo & 689.6 & 842.9 & 944.5 & 1041.9 & 1072.8 & 1167.9 \\
\hline \multirow{3}{*}{ Station of the two forest sites } & Aneho & 682.1 & 893.6 & 1033.7 & 1168.1 & 1210.7 & 1341.9 \\
\hline & Athieme & 636.3 & 812.0 & 928.4 & 1040.0 & 1075.5 & 1184.5 \\
\hline & Grand-Popo & 640.4 & 866.8 & 1016.6 & 1160.4 & 1206.0 & 1346.5 \\
\hline \multicolumn{8}{|c|}{ Thresholds rates $\left(\mathrm{m}^{3}\right)$ of annual daily flow for flood risks } \\
\hline \multicolumn{2}{|l|}{ Flows jauge station at Athieme } & 568.9 & 772.5 & 907.3 & 1036.5 & 1077.5 & 1203.8 \\
\hline
\end{tabular}

$824.6 \mathrm{~mm}, 927.1 \mathrm{~mm}$ and $1025.3 \mathrm{~mm}$.

On the Naglanou and Akissa forest sites scale, rare frequency total seasonal rainfall $(\geq 25$ years or $=50$ years) which can lead to exceptional hydrological events are respectively 1072.8 to $1210.7 \mathrm{~mm}$ and 1167.9 to $1346.5 \mathrm{~mm}$. Seasonal cumulative rainfall are 636.3 to $689.6 \mathrm{~mm}$ for 2 years return period; 812.0 to $893.6 \mathrm{~mm}$ for 5 years'; 928.4 to $1016.6 \mathrm{~mm}$ for 10 years' and from 1040.0 to $1160.4 \mathrm{~mm}$ for 20 years'.

In comparison, the years 1999, 2010 hydro-climatic events, in the Mono Basin, are comparable to those of 1963, 1968, but less intense. This confirms to certain extent a certainty of exceptional hydrological events return periods on the basin and in particular the two forest sites.

These frequent events of hydro-climatic disasters could be due not only to slight increase in rainfall but certainly also to combined effect of water releases from Nangbéto dam and vegetation cover degradation of in the basin.

\section{DISCUSSION}

In the current context of hydroloclimatic variation, it is important to quantify the impact on the hydrosystems. Thus, this study investigated climate and hydrological variation in the Mono River basin and to determine flood risk for ecological conservation of the Naglanou (Benin) and Akissa (Togo) hydrosystems. Relationship between rainfall and flow is perfect $(r=0.64)$ on the Mono River basin of 1961-2010. This flow dependence on rainfall is also highlight in Niger River basin (0.81) by Vissin (2007) on 1955-1992 and 0.65 by Babatolu and Akinnubi (2014) on 1955-2010. But, in the White Volta River basin at Pwalugu, this correlation coefficient is 0.78 over the period 2003-2009 (Kasei et al., 2013) on due to largely dependence of surface runoff on rainfall of the basin. Thus, these peaks of hydrological flow succeed the rainfall peak with a two to three lag month corresponding to the basin response time and soil horizons saturation. This corroborates the results of Totin et al. (2016) on the Ouémé River basin at Bonou. Nevertheless, the correlation gap could be linked land use land cover (Mahé, 2006; Tramblay et al., 2014; Roudier et al., 2014). In recent decades West Africa has seen major changes in land use, with strong impacts on runoff (Wittig et al., 2007).

These rainfall variations have led to strong fluctuations in river discharge with a generally negative trend from 1960 to 2010 (Descroix et al., 2013), especially in Sudanian areas. In Guinean areas the decrease has been more moderate. Mahe et al. (2013) underlined the nonlinear effect of this rainfall drop over much of West Africa, with a $-20 \%$ decrease in rainfall resulting in a decrease of $-60 \%$ in runoff.

Runoff coefficient average at Athieme station is $20.38 \%$ over 1961-2015 against 14\% over the period 1961-2000 (Amoussou et al., 2012). Increasing flow coefficient is the direct result of improved rainfall on the decades 1990 and 2000, degradation of vegetation cover (Mahe and Olivry, 1995; Dhakal et al., 2012; Tramblay et al., 2014) increase of evapotranspiration, rising of the subsurface aquifer and presence of sandstone covered by hydromorphic soils with low retention capacity.

Monthly flow coefficient which was $2.3 \%$ (1961 to 1987 ) has almost increased (4.4\%) between the years 1988 and 2015 mainly confirming significant contributions of Nangbéto dam in dry periods as already reported by Blivi and Rossi (1995) and Klassou (1996). This is an advantage in terms of water balance for Naglanou and Akissa areas biodiversity.

Studies concerning climate variability in the Mono River watershed revealed a slight increase of precipitation in the period after 1990 (Amoussou et al., 2012; Houéssou et al., 2015). Cumulative seasonal rainfall (May to October) is the mean factors of flood risk on the areas of Naglanou and Akissa.

Floodplain connectivity indicates a broad range of 
ecological functions including the current and potential floodplain connectivity indicates a broad range of ecological functions including the current and potential capacity of floodplains to store and convey floods, transport sediment and wood, retain and transform water pollutants, support forest ecosystems, and provide habitats for aquatic species, ....

In addition, flooding poses a risk to many facilities located on floodplain including those that provide vital services (Konrad, 2015). Thus, frequent floods are read preferable than eventual floods for a better conservation of the ecosystems. Then, the lower return period ( 2 to 5 years) is desirable than the maximum return period (10 to 20 years), due to its almost permanent moisture role in the biodiversity conservation on the Naglanou and Akissa forests.

\section{Conclusion}

It appears that water availability in Naglanou Akissa forest sites depends on temporal distribution of rainfall, Mono River flows and its tributaries during periods of high water especially floods and dam Nangbéto water releases. The latter contributed to $97 \%$ of runoff in time of base flow in the basin and therefore to soils moistening.

Flow coefficient increase from $20.38 \%(1961-2015)$ to $14 \%$ (1961-2000) confirms rainfall increase since the end of the 1990s and Nangbéto dam water releases in the basin. Morphological, pedo-geological and hydro-climatic factors induced large water accumulation on Naglanou and Akissa forest areas. So water reserve varies from 0.03 to $97 \%$ depending on the seasons, but more pronounced in the wet' period (from 20.48 to $97 \%$ ). Forest areas have a high water retention capacity. This is a great advantage for the conservation of aquatic and semi- aquatic biodiversity on these areas.

Characterization of flood hazards on Naglanou and Akissa areas is determined from the categorization of rainfall and hydrometric thresholds. The different hazards thresholds determined are ranked in terms of limited $\left(424.8 \mathrm{~m}^{3} \cdot \mathrm{s}^{-1}\right)$, moderate $\left(609.3 \mathrm{~m}^{3} \cdot \mathrm{s}^{-1}\right)$, significant $(709.1$ $\left.\mathrm{m}^{3} \cdot \mathrm{s}^{-1}\right)$, and critical $\left(824.1 \mathrm{~m}^{3} \cdot \mathrm{s}^{-1}\right)$. Significant and critical thresholds for orange and red warning levels associated with rare frequency events are sometimes catastrophic for a biodiversity.

Return periods of flood hazards are at least 20 to 50 years for rare and very rare events, but more disastrous than events of a range from 2 to 10 years frequency. These cases are the most desired events for the protection of ecological habitat and aquatic biota.

Facing the Naglanou and Akissa forest areas vulnerability to floods, the subject of the next step will focus on development of an early warning system for hydro-climatic crises efficient management and better ecological monitoring.

\section{CONFLICT OF INTERESTS}

The authors have not declared any conflict of interests.

\section{ACKNOWLEDGEMENTS}

This study was realized with the financial support of the GIZ project "Transboundary Biosphere Reserve of the Mono Delta". The project is part of the International Climate Initiative (IKI), supported by the German Federal Ministry for Environment, Nature Conservation, Building and Nuclear Safety (BMUB). Authors wish to thank also the local curators of the Naglanou (Benin) and Akissa (Togo) forest sites, the associated editor and reviewers for their relevant comments.

The authors wish to thank the Associated Editor, and an anonymous reviewer for their useful comments on the manuscript.

\section{REFERENCES}

Amemiya T (1980). Selection of regressors. Int. Econ. Rev. 21:331-354. Amoussou E, Camberlin P, Mahé G (2012). Impact de la variabilité climatique et du barrage Nangbéto sur l'hydrologie du système Mono-Couffo (Afrique de l'Ouest). Hydrol. Sci. J. 57(4):805-817.

Babatolu JS, Akinnubi RT (2014). Influence of Climate Change in Niger River Basin Development Authority Area on Niger Runoff, Nigeria. J. Earth Sci. Clim. Chang. 5:230.

Beck HE, Bruijnzeel LA, Van Dijk AlJM, McVicar TR, Scatena FN Schellekens J (2013). The impact of forest regeneration on streamflow in mesoscale humid tropical catchments. Hydrol. Earth Syst. Sci. 17(7):2613-2635.

Bois P, Obled C, Zin I (2007). Introduction au traitement de données en hydrologie. 7ème édition revue et complétée - Janvier 2007. L'Edition du Millénaire, $256 \mathrm{p}$.

Bonaccorso B, Bordi I, Cancelliere A, Rossi G, Sutera A (2003). Spatial Variability of Drought: An Analysis of the SPI in Sicily. Water Resour. Manag. 17(4):273-296.

Bordi L, Cioci F, Camilloni G (2001). In vivo binding and hierarchy of assembly of the yeast RNA polymerase I transcription factors. Mol. Biol. Cell 12(3):753-760.

Cancelliere A, Bonaccorso B (2009). Uncertainty analysis of the Standardized Precipitation Index in the presence of trend. Hydrol. Days pp. 14-26.

Davis SD, Heywood VH, Hamilton AC (1994). Centers of plant diversity: a guide and strategy for their conservation. Volume 1. Europe, Africa, South West Asia and Middle East. IUCN and WWF, Gland, Switzerland, $354 \mathrm{p}$.

Descroix L, Moussa IB, Genthon P, Sighomnou D, Mahé G, Mamadou I, Vandervaere JP, Gautier E, Maiga OF, Rajot JL, Abdou MM, Dessay $\mathrm{N}$, Ingatan A, Noma I, Yéro KS, Karambiri H, Fensholt R, Albergel J, Olivry JC (2013). Impact of Drought and Land - Use Changes on Surface - Water Quality and Quantity: The Sahelian Paradox, Curr. Perspect. Contam. Hydrol. Water Res. Sustain., in: Current Perspectives in Contaminant Hydrology and Water Resources Sustainability, chap. 10, edited by: Bradley, P. M., pp. 243-271.

Deutsche Gesellschaft für Internationale Zusammenarbeit (GIZ) (2016). Caractérisation hydrologique des forets de Naglanou (Bénin) et d'Akissa (Togo) pour la gestion des risques d'inondations dans le delta du Mono. Rapport de consultation, $56 \mathrm{p}$.

Dhakal N, Fang X. Cleveland TG, Thompson DB, Asquith WH, Marzen LJ (2012). Estimation of Volumetric Runoff Coefficients for Texas Watersheds Using Land-Use and Rainfall-Runoff Data. J. Irrigation 
Drainage Eng. pp. 43-54.

Di Minin E, Soutullo A, Bartesaghi L, Rios M, Nube Szephegyi M, Moilanen A (2017). Integrating biodiversity, ecosystem services and socio-economic data to identify priority areas and landowners for conservation actions at the national scale. Biol. Conserv. 206:56-64.

Diakakis M (2012). Rainfall thresholds for flood triggering. The case of Marathonas in Greece. Nat. Hazards 60(3):789-800.

Doumenge C, GarciaYuste JE, Gartlan S, Langrand O, Ndinga A (2001). Conservation de la biodiversité forestière en Afrique centrale atlantique: le réseau d'aires protégées est-il adéquat ? Bois et forêts des tropiques, 268(2):5-27.

Du J, Fang J, Xu W, Shi PJ (2013). Analysis of dry/wet conditions using the standardized precipitation index and its potential usefulness for drought/flood monitoring in Hunan Province, China. Stockholm Environ. Resour. Risk Assess. 27:377-387.

Dudley N, Buyck C, Furuta N, Pedrot C, Renaud F, Sudmeier-Rieux K (2015). Protected Areas as Tools for Disaster Risk Reduction. A handbook for practitioners. Tokyo and Gland, Switzerland: MOEJ and IUCN, $44 \mathrm{p}$.

Dutra E, Di Giuseppe F, Wetterhall F, Pappenberger F (2013). Seasonal forecasts of droughts in African basins using the Standardized Precipitation Index. Hydrol. Earth Syst. Sci. 17(6):23592373.

Fournier A, Sinsin B, Mensah GA (2007). Quelles aires protégées pourl'Afrique de l'Ouest ? Actes du Séminaire International sur l'Aménagement et la Gestion des Aires Protégées en Afrique Centrale et de l'Ouest. Parakou, Bénin 2003. Editions IRD, France. ISBN 978-2-7099-1634-9; ISSN 0767-2896. 606 p.

Game ET, Lipsett-Moore G, Saxon E, Peterson N, Sheppard S (2011). Incorporating climate change adaptation into national conservation assessments. Glob. Chang. Biol. 17:3150-3160.

GFDRR (2012). Stratégie de partenariat du GFDRR 2009-2012 Prévenir les risques de catastrophes pour un développement durable, Rapport technique, $24 \mathrm{p}$.

Ghanmi H (2014). Estimation des courbes Intensité-Durée-AireFréquence (IDAF) de la région de Tunis dans un contexte multi fractal. Thèse de Doctorat, Université de Tunis El Manar, Tunisie, 154 p.

Goula BTA, Savané I, Konan B, Fadika V, Kouadio BG (2006). Impact de la variabilité climatique sur les ressources hydriques des bassins de N'zo et N'zi en Côte d'Ivoire (Afrique tropicale humide). VertigO-la revue électronique en sciences de l'environnement. 7(1):1-12.

Guerreiro MJ, Lajinha T, Abreu I (2008). Flood Analysis with the Standardized Precipitation Index (SPI). Revista da Faculdade de Ciênca e Tecnologia, 4:8-14.

Hennequi M (2010). Spatialisation des données de modélisation par Krigeage. Master Statistique et Applications, Université de Strasbourg, $75 \mathrm{p}$.

Houéssou S, Amoussou E, Totin VSH, Semondji GE, Ago E, Houndénou C (2015). Influence de l'exploitation de la centrale hydroélectrique de Nangbéto sur les écosystèmes de la basse vallée du fleuve Mono. In "Climat et Développement", LACEEDE/FLASH/UAC, pp. 5-17.

Houndénou C (1999). Variabilité climatique et maïsiculture en milieu tropical humide : L'exemple du Bénin, diagnostic et modélisation. Thèse de Doctorat, Université de Bourgogne, Dijon. 390 p.

Hubert P, Bendjoudi H (1997). Caractéristiques fractales des séries pluviométriques, FRIEND Flow Regime from International Experimental and Network Data, Projets H- 5-5 (IHP IV) and 1.1 (IHP V) Third report: 1994-1997, CEMAGREF éditions, pp. 352-356.

Hughes F, Richards K, Girel J, Moss T, Muller E, Nilsson C, Rood S (2003). The Flooded Forest: Guidance for policy makers and river managers in Europe on the restoration of floodplain forests. The FLOBAR2 Project, Department of Geography, University of Cambridge, $96 \mathrm{p}$

Intergovernmental Panel on Climate Change (IPCC) (2001). Climate Change: Impacts, Adaptation and Vulnerability: A Report by the Intergovernmental Working Panel on Climate Change. 22p.

IPCC (2001). Incidences de l'évolution du climat dans les régions : Rapport spécial sur l'Evaluation de la vulnérabilité en Afrique. Island
Press, Washington, $53 \mathrm{p}$.

Jobson JD (1992). Applied Multivariate Data Analysis: Volume 2: Categorical and Multivariate Methods. Springer Verlag, New York, XXIX, $732 \mathrm{p}$.

Karavitis AC, Alexandris S, Tsesmelis ED, Athanasopoulos D (2011). Application of the Standardized Precipitation Index (SPI) in Greece. Water, 3(4):787-805.

Kasei AR, Ampadu B, Sapanbil GS (2013). Relationship between Rainfall-Runoff on the White Volta River at Pwalugu of the Volta Basin in Ghana. J. Environ. Earth Sci. 3(11):92-99.

Khadr M, Morgenschweis G, Schlenkhoff A (2009). Analysis of meteorological drought in the Ruhr basin by using the standardized precipitation index. World Acad. Sci. Eng. Technol. 57:607-616.

Klassou SD (1996). Evolution climato-hydrologique récente et conséquences sur l'environnement : l'exemple du bassin versant du fleuve Mono (Togo-Bénin). Thèse de Doctorat, Université de Bordeaux III, $472 \mathrm{p}$.

Konrad CP (2015). Geospatial assessment of ecological functions and flood-related risks on floodplains along major rivers in the Puget Sound Basin, Washington: U.S. Geological Survey Scientific Investigations Report 2015-5033, 28p.

Kukkala AS, Moilanen A (2013). Core concepts of spatial prioritisation in systematic conservation planning. Biol. Rev. 88:443-464.

Kullberg P, Moilanen A (2014). How do recent spatial biodiversity analyses support the convention on biological diversity in the expansion of the global conservation area network? Nat. Conserv. 12:3-10.

Lloyd-Hughes B, Saunders MA (2002). A drought climatology for Europe. Int. J. Climatol. 22:1571-1592.

Lubès $H$, Masson JM (1991). Méthode des moments de probabilite pondérés Application à la loi de Jenkinson. Hydrol. Continent. 6(1):67-84.

Mahé G, Olivry JC (1995). Variations des précipitations et des écoulements en Afrique de l'ouest et centrale de 1951 à 1989. Sécheresse, 6(1):109-117.

Mahe G, Lienou G, Descroix L, Bamba F, Paturel JE, Laraque A, Meddi M, Habaieb H, Adeaga O, Dieulin C, Chahnez Kotti F, Khomsi K (2013). The rivers of Africa: witness of climate change and human impact on the environment, Hydrol. Process 27:2105-2114.

Mahé G, Olivry JC, Dessouassi R, Orange D, Bamba F, Servat E (2000). Relations eaux de surface-eaux souterraines d'une rivière tropicale au Mali. C.R. Acad. Sci. Paris, Sciences de la Terre et des planètes $n^{\circ} 330: 689-692$

McKee TB, Doesken NJ, Kleist J (1993). The relationship of drought frequency and duration of time scales. Eighth Conference on Applied Climatology, American Meteorological Society, Anaheim CA, pp. 179186.

Mengue-Medou C (2002). Les aires protégées en Afrique : perspectives pour leur conservation.

Mimikou MA, Niadas LA, Jmidjissavva PS, Kolivopoulos YS (1994). Regional techniques for extreme rainfall and runoff prediction. Hydrol. Continent .9(1):25-32.

Mounier J, Dubreuil V, Henaff $F$ (1993). Sécheresses et rivières en Bretagne Occidentale», dans l'eau, la terre et les hommes, Mélanges en l'honneur de R. Frécaut, Nancy, Presses Universitaires de Nancy, pp. 263-272.

Ngandjui G, Blanc CP (2000). Biogéographie et biodiversité: aires protégées et conservation des mammifères au Cameroun. Biogeographica 76(2):63-77.

Paturel JE, Servat E, Delattre MO (1998). Analyse de séries pluviométriques de longue durée en Afrique de l'Ouest et Centrale non sahélienne dans un contexte de variabilité climatique. J. Sci. Hydrol. 43(6):937-945.

Rossi G, Blivi AB (1995). Les conséquences des aménagements hydrauliques de la vallée du Mono (Togo-Bénin). S'aura-t-on gérer l'avenir? Cahiers d'Outre-mer, 48(192):435-452.

Roudier P, Ducharne A, Feyen L (2014). Climate change impacts on runoff in West Africa: a review Hydrol. Earth Syst. Sci. 18:2789-2801.

Savané I, Coulibaly K, Gioan P (2001). Variabilité climatique et ressources en eaux souterraines dans la région semi-montagneuse 
de Man. Sécheresse, 12:231-237.

Seiler RA, Hayes M, Bressan L (2002). Using the standardized precipitation index for flood risk monitoring. Int. J. Climatol. 22(11):1365-1376.

Totin VSH, Amoussou E, Odoulami L, Boko M, Blivi BA (2016). Seuils pluviométriques des niveaux de risque d'inondation dans le bassin de l'Ouémé au Bénin (Afrique de l'ouest). Actes du XXIXe Colloque de l'Association Internationale de Climatologie, Besançon, France, (Sous presse).

Totin VSH, Clédjo P, Afouda A, Boko M (2009). Variabilité pluviométrique et bilan climatique dans le bassin de la volta au Bénin. Clim. Dev. 8:81-94.

Tramblay Y, Amoussou E, Dorigo W, Mahé G (2014). Flood risk under future climate: linking extreme value models and flood generating processes. J. Hydrol. 519:549-558.

Trenberth KE, Dai A, van der Schrier G, Jones PD, Barichivich J, Briffa $\mathrm{KR}$, Sheffield J (2014). Global warming and changes in drought. Nat. Clim. Chang. 4(1):17-22.
Vicente-Serrano MS, Begueria S, Lopez-Moreno IJ (2010). A Multiscalar Drought Index Sensitive to Global Warming: The Standardized Precipitation Evapotranspiration Index. J. Clim. 23(7):1696-1718.

Vissin EW (2007). Impact de la variabilité climatique et de la dynamique des états de surface sur les écoulements du bassin béninois du fleuve Niger. Thèse de Doctorat; Université de Bourgogne, Dijon, 311 p.

Wittig R, König K, Schmidt M, Szarzynski J (2007). A Study of Climate Change and Anthropogenic Impacts in West Africa. Environ. Sci. Pollut. Res. 14:182-189.

World Meteorological Organization (WMO), (2012). Standardized precipitation index user guide (M. Svoboda, M. Hayes and D. Wood), WMO-No. 1090, Geneva 2, 16 p.

Xie H, Ringler C, Zhu T, Waqas A (2013). Droughts in Pakistan: A spatiotemporal variability analysis using the Standardized Precipitation Index. Water Int. 38(5):620-631. 